\title{
Blood parameters of lambs fed diets with vegetable oil supplements
}

\author{
A. Cieślak ${ }^{1,3}$, A. Potkański', M. Szumacher-Strabel ${ }^{1}$ \\ and J. Kowalczyk ${ }^{2}$ \\ 'Department of Animal Nutrition and Feed Management. \\ August Cieszkowski Agricultural University \\ Wolyńska 33, 60.637 Poznañ, Poland \\ ${ }^{2}$ The Kielanowski Institute of Animal Phvsiology and Nutrition, Polish Academy of Sciences \\ 05-110 Jablonna, Poland
}

\section{ABSTRACT}

The effect of different types of dietary fat on rumen parameters was assessed on four lambs with rumen cannulae in a $4 \times 4$ Latin square design. The basic ration for the control group consisting of meadow hay and concentrate (40:60) was supplemented for the experimental groups with 5\% of rapesced, sunflower or linseed oil. Volatile fatty acids, ammonia concentration and $\mathrm{pH}$ in rumen fluid, and glucose, free fatty acids, cholesterol and triglycerides in blood were determined. The propionic acid level was lower $(P<0.05)$ in rumen fluid when $5 \%$ of rapeseed oil was added to the ration. Addition of rapeseed oil or linseed oil decreased blood glucose level.

KEY WORDS: oils, blood parameters, lipid metabolism, VFA, lambs

\section{INTRODUCTION}

Fats rich in chemopreventive agents, conjugated linoleic acid (CLA) and trans C 18:1 fatty acids may affect lipid and glucose metabolism (Selberg et al., 2004), improve the metabolic efficiency of some organs and the health of the animal (Hocquette and Bauchar1, 1999). However, a number of studies reported that diets high in fat, especially in saturated fatty acids, increase the level of cholesterol and free fatty acids in blood. This study was carried out to assess the effect of vegetable oils in lamb rations on the blood metabolites and rumen parameters describing lipid metabolism.

\section{MATERIAL AND METIIODS}

The experiment was carried out in a $4 \times 4$ Latin square design on 4 Whitehead meat type lambs fitted with permanent rumen cannulae. The basic diet (1.07 UFM, $105 \mathrm{~g}$

\footnotetext{
$\overline{{ }^{3} \text { Corresponding author: e-mail: adamck@jay.au.poznan.pl }}$
} 
PDIN and $106 \mathrm{~g}$ PDIE) for the control group comprised hay and concentrate (40:60\%), supplemented for the experimental groups with $5 \%$ (DM basis) of rapeseed, sunflower or linseed oil. The animals were adapted to the diet for 14 days and during the next 2 days of each period samples of blood and rumen fluid were collected.

Samples of rumen fluid were collected before the morning feeding and 3 and 6 $\mathrm{h}$ after feeding. The samples were analysed for $\mathrm{pH}$, ammonia (modified Nesslers' method) and volatile fatty acids (VFA) according to Tangerman and Nagengast (1996). Blood samples were obtained from the jugular vein at the same time as the rumen fluid and were analysed for free fatty acids (colorimetric methods by Dancomba), glucose (GOD-PAP, method; Polfam Dialab ${ }^{\circledR}$ ), triglycerides (GODPAP method; Polfam Dialab ${ }^{\circledR}$ ) and cholesterol (ChOD-PAP method; Polfam Dialab $\left.^{\circledR}\right)$.

Data were analysed by the ANOVA software programme for a Latin square design by using the General Linear Models procedure of SAS (1996).

\section{RESULTS}

Supplementing vegetable oil to the diets significantly $(\mathrm{P}<0.05)$ influenced only the glucose concentrations in the blood samples collected before feeding, which were higher in the control $(85.8 \mathrm{mg} / \mathrm{dL})$ and $\mathrm{SFO}(82.3 \mathrm{mg} / \mathrm{dL})$ groups than in groups RSO and LSO (68.2 and $68.6 \mathrm{mg} / \mathrm{dL}$ ). Differences between the effect of the oils on the concentrations of triglycerides, cholesterol and free fatty acids and time after feeding did not reach statistical significance $(\mathrm{P}>0.05)$.

Supplementation of diets with $5 \%$ of RSO decreased $(\mathrm{P} \leq 0.05)$ the level of propionic acid, whereas SFO and LSO did not cause such an effect (Table 1). An increasing tendency in acetic, propionic and butyric acid levels in the rumen 3 and $6 \mathrm{~h}$ after feeding was found compared with samples taken before feeding.

Vegetable oils, especially $5 \%$ of rapeseed oil, decreased the level of rumen ammonia but the differences were not statistically significant (Figure 1). Rumen $\mathrm{pH}$ remained stable regardless of the added fat and time after feeding (Figure 1).

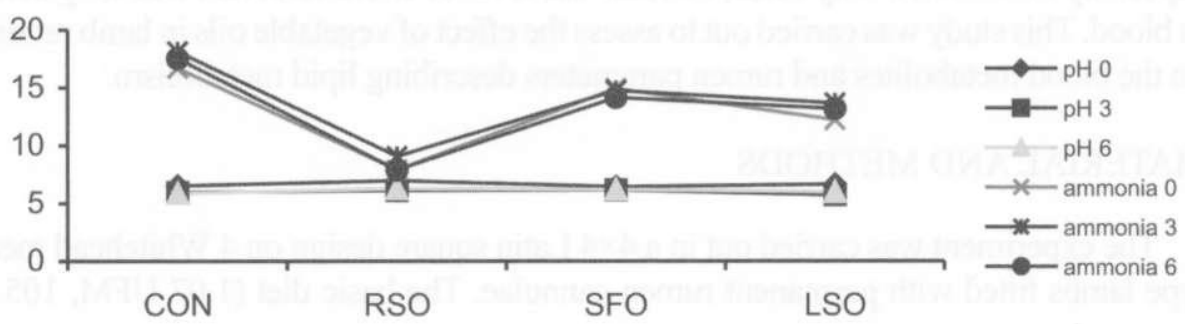

Figure 1. Effect of supplementing different oils to lamb rations on the concentration of rumen ammonia $(\mathrm{mmol} / \mathrm{L})$ and $\mathrm{pH}$ 
TABLE 1

Effect of vegetable oils on the concentration of individual VFA in the rumen of sheep, $\mathrm{mmol} / \mathrm{I}$.

\begin{tabular}{|c|c|c|c|c|c|}
\hline \multirow{2}{*}{ Item } & \multicolumn{4}{|c|}{ Type of added oil } & \multirow{2}{*}{ SFM' } \\
\hline & control & $\mathrm{RSO}^{*}$ & $\mathrm{SHO}^{* *}$ & $\mathrm{LSO}^{* * *}$ & \\
\hline \multicolumn{6}{|l|}{ Acetate } \\
\hline before feeding & 44.64 & 32.77 & 34.48 & 33.59 & 15.42 \\
\hline $3 \mathrm{~h}$ after feeding & 55.06 & 47.16 & 45.07 & 44.83 & 20.16 \\
\hline $6 \mathrm{~h}$ after feeding & 54.23 & 46.93 & 47.41 & 46.84 & 21.20 \\
\hline \multicolumn{6}{|l|}{ Propionate } \\
\hline before feeding & 15.89 & 11.81 & 13.88 & 14.02 & 6.21 \\
\hline $3 \mathrm{~h}$ after leeding & $24,87^{\mathrm{aa}}$ & $17.01^{\mathrm{bb}}$ & $21.41^{\mathrm{ah}}$ & $25.81^{* 3 / 3}$ & 9.58 \\
\hline $6 \mathrm{~h}$ after leeding & 26.36 & 17.65 & 22.92 & 25.60 & 10.25 \\
\hline \multicolumn{6}{|l|}{ Iso-butyrate } \\
\hline before feeding & 1.77 & 1.38 & 1.45 & 1.40 & 0.65 \\
\hline $3 \mathrm{~h}$ after feeding & 1.92 & 1.34 & 1.24 & 1.39 & 0.56 \\
\hline $6 \mathrm{~h}$ after feeding & 1.87 & 1.23 & 1.13 & 1.10 & 0.50 \\
\hline \multicolumn{6}{|l|}{ Butyrate } \\
\hline before feeding & 11.64 & 7.04 & 9.38 & 10.14 & 4.19 \\
\hline $3 \mathrm{~h}$ after leeding & 14.57 & 10.13 & 13.13 & 15.93 & 5.87 \\
\hline $6 \mathrm{~h}$ after feeding & 15.05 & 10.51 & 12.21 & 18.35 & 5.46 \\
\hline \multicolumn{6}{|l|}{ Iso-valerate } \\
\hline before fceding & 0.86 & 0.79 & 0.67 & 0.64 & 0.30 \\
\hline $3 \mathrm{~h}$ after fecding & 0.87 & 0.71 & 0.62 & 0.75 & 0.28 \\
\hline $6 \mathrm{~h}$ after fecding & 0.94 & 0.74 & 0.61 & 0.66 & 0.27 \\
\hline \multicolumn{6}{|l|}{ Valerate } \\
\hline before feeding & 1.34 & 1.04 & 0.90 & 1.21 & 0.40 \\
\hline $3 \mathrm{~h}$ after feeding & 1.57 & 1.22 & 1.57 & 2.23 & 0.70 \\
\hline $6 \mathrm{~h}$ after feeding & 2.07 & 1.37 & 1.43 & 2.18 & 0.64 \\
\hline
\end{tabular}

' $S E M$ - mean standard error: means in rows with the same letter are not significantly different a.b- P $\leq 0.05$, "RSO - rapeseed oil, " $\mathrm{SFO}$ - sunflower oil, " "* LSO - linseed oil

\section{DISCUSSION}

The effect of supplementing fat to ruminants' rations depends on the level supplementation and the oil's fatty acid composition. Dietary fats undergo biohydrogenation. The degree of saturation of dietary fat influences digestion and absorption of fat (Oldick et al., 1997), and hence rumen and blood parameters. Saturated fatty acids seem to have a more detrimental effect on lipid metabolism parameters than unsaturated ones, and usually have resulted in increased blood levels of metabolites (e.g., cholesterol, free fatty acids) and changed proportions of individual fatty acids in the rumen. This hypothesis may explain the results of our research, in which different vegetable oils, sources of unsaturated fatty acids, C 18:1, C 18:2 and C 18:3, generally had no effect on basic blood and rumen parameters, except on glucose when RSO and LSO were added, and on propionic 
acid with RSO. Similarly, according to Petit ct al. (2002) and Rigout et al. (2003), fluctuations in the glucose level did not reflect the quantity and proportions of VFA. The observed decreased level of ammonia can be explained according to Doreau and Ferlay (1995) by the detrimental effect of fat supplements, especially RSO, on microbial synthesis in the rumen. Addition of $5 \%$ rapeseed, sunflower or linseed oils to lambs rations as energy supplements and meat fatty acid composition modifiers seems to be a safe quantity.

\section{REFERENCES}

Doreau M., Ferlay A., 1995. Effect of dietary lipids on nitrogen metabolism in the rumen: a review. Livest. Prod. Sci, 43, 97-110

Hocquette J.F., Bauchart D., 1999. Intestinal absorption. blood transport and hepatic and muscle metabolism of fatty acids in preruminant and ruminant animals. Reprod. Nutr. Dev. 39, 27-48

Oldick B.S.. Staples C.R., Thatcher W.W., Gyawu P., 1997. Abomasal infusion of glucose and fat-effect on digestion, production and ovarian and uterine function of cows. J. Dairy Sci. 80 , $1315-1328$

Petit H.V., Dewhurst R.J., Scollan N.D., Prolux J.G., Khalid M., Haresign W., Twagiramungy H., Mann G.F., 2002. Milk production and composition of ovarian function and prostaglandin secretion of dairy cows fed omega- 3 fats. J. Dairy Sci. 85, 889-899

Rigout S., Hurtaud C., Lemosquet S., Bach A., Rulquin H., 2003. Lactation effect of propionic acid and duodenal glucose in cows. J. Dairy Sci. 86, 243-253

SAS, 1996. SAS/STAT Users Guide (Release 6.12). SAS Institute Inc., Cary. NC6-USA

Selberg K.'T., Lowe A.C., Staples C.R., Luchini N.D., Badinga L., 2004. Production and metabolic responses of periparturient Holstein cows to dietary conjugated linoleic acid and transoctadecenoic acids. J. Dairy Sci. 87, 158-168

Tangerman A., Nagengast F.M., 1996. A gas chromatographic analysis of fecal short-chain fatty acids, using the direct injection method. Anal. Biochem. 236, 1-8

\section{STRESZCZENIE}

\section{Poziom wskaźników w krwi jagniąt żywionych paszami z dodatkiem olejów roślinnych}

Doświadczenic przeprowadzono $w$ układzic kwadratu łacińskicgo $4 \times 4$ na czterech jagniętach typu mięsnego z kaniulami do żwacza. Podstawowa dawka pokarmowa składała się z paszy treściwej i objętościowej w stosunku 60:40 (kontrolna), 7 . dodatkiem 5\% oleju rzepakowego, słonecznikowego lub Inianego w suchej masie dawki w grupach kontrolnych. Dodatek $5 \%$ oleju rzepakowego oraz lnianego statystycznic istotnic $(\mathrm{P}<0,05)$ obniżył poziom glukozy we krwi, natomiast $5 \%$ oleju rzepakowego obniżył poziom kwasu propionowego $(\mathrm{P}<0,05) \mathrm{w}$ treści żwacza. Nie stwierdzono istotnych zmian poziomu pH oraz stężenia amoniaku w żwaczu jagniąt żywionych dawką z dodatkiem badanych olejów. 